\title{
The effectiveness of direct sowing technology in the cultivation of spring wheat in the conditions of the forest-steppe zone of the Volga region
}

\author{
Aleksander Toigildin*, Mikhail Podsevalov, Denis Ayupov, and Valery Syromyatnikov \\ Ulyanovsk State Agrarian University named after P.A. Stolypin, 432017 Ulyanovsk, Russia
}

\begin{abstract}
The article presents the results of the effectiveness studies of No-till technology on chernozem in a typical forest-steppe zone of the Volga region. Research has shown that No-till technology provides water, agrophysical and agrochemical properties of soil that are favourable for plant growth while effectively controlling weeds. There is also a tendency to increase the yield and product quality. According to our estimates, direct sowing increases the yield of spring wheat grain by $0.5 \mathrm{~kg} / \mathrm{ha}$, the mass fraction of gluten from $13.6 \%$ to $15.0 \%$, the mass fraction of protein from $11.0 \%$ to $11.6 \%$ in comparison with traditional technology.
\end{abstract}

\section{Introduction}

Priority areas for the development of agriculture on a global scale include the search for effective, low-cost, environmentally acceptable agricultural technologies that guarantee the stable development of agricultural production while reducing the cost and the negative impact of intensification means on the environment.

In recent years, minimal tillage systems and No-till technologies [1] are becoming more widespread in the world, including in Russia [2]. The modern strategy of the No-till system provides for a gradual transition to soil-protective and energy-saving agriculture based on the development of biologization techniques [3].

The technology meets certain requirements. It minimizes interference with the soil while ensuring the constant presence of plants and their live roots in the soil, maintaining fertility, reducing the cost of fuels and lubricants, depreciation and repair of equipment. This is not a simplification of existing systems, but a sophisticated technology, the correct application of which minimize the main problems of agriculture $[4,5]$.

The advantage of No-till technology lies in several aspects. The technology will allow the accumulation of plant residues of previous crops on the surface, which provides the soil with wind resistance, reduces unproductive evaporation of moisture, protects plants from weediness, reduces losses of organic matter and others [6]. Some scientists and practitioners evaluate the effectiveness of the No-till system differently. So in their opinion, the development of this system increases crop yields in about $15 \%$ of cases, in 5\% there is a decrease, and the yield does not change in $80 \%$ of cases comparing with traditional methods of land use [7].

The methodology of studying No-till technology in Russia is in the stage of development. Only individual enterprises have appreciated the advantage of this technology and successfully continue to learn and implement it. Given the territorial fragmentation, the diversity of soil and climatic conditions, scientists have to undertake many studies and design practical recommendations for the development of this technology.

Purpose of the study: to evaluate the efficiency of No-till technology on chernozem typical in the conditions of the forest-steppe zone of the Volga region.

The tasks include:

- to study the dynamics of the agrophysical properties of the soil, depending on the technologies used;

- to study the dynamics of soil moisture and the content of productive moisture with various technologies;

- to identify changes in agrochemical indicators of soil fertility;

- to establish the effect of No-till technology on weediness of crops;

- to study the dependence of the spring wheat yield and its structure on the studied factors.

\section{Research Methodology}

The studies were carried out in the production environment of LLC Agrostandart of the Novospassky district of the Ulyanovsk region.

The soil of the experimental plot is a typical carbonate light loamy chernozem. The content of humus in the soil is $6.05 \%$, the reaction of the soil solution is neutral $\left(\mathrm{pH}_{\mathrm{KCl}}=6.86\right)$, the content of mobile phosphorus is $149 \mathrm{mg} / \mathrm{kg}$ of soil, exchange potassium is $220 \mathrm{mg} / \mathrm{kg}$ of soil, sulfur is $11 \mathrm{mg} / \mathrm{kg}$ of soil. 
The object of research is spring wheat, located in a grain-crop rotation: clean fallow - winter wheat sunflower - barley - soybeans - spring wheat. We studied two options for sowing technology and protecting plants from weediness: 1) combined tillage as the main one in crop rotation, applying herbicide to protect plants from weediness during plant vegetation 2) direct sowing of all crops, chemical protection of crops from weeds in spring, summer and autumn periods.

Combined cultivation of the soil in a crop rotation involved ploughing under sunflower and soybean to a depth of 25-27 cm. For grain crops (barley, spring wheat), we used shallow tillage included double-disking of 10-12 cm, early spring harrowing and sowing with a DMC seeder -9000. In the second option, we did not cultivate the soil after harvesting; in the spring we carried out the direct sowing with the Amazone DMC9000 seeder. The sowing rate of spring wheat is 4 million pcs germinating seeds per 1 ha, the variety is Grani.

We conducted the research using generally accepted methods $[8,9]$.

The research period (2019) had arid conditions with $36 \mathrm{~mm}$ of precipitation on May, which is $10 \%$ lower than normal, while the hydrothermal coefficient (HTC) was 0.70 units, and on June $8.4 \mathrm{~mm}$ of precipitation fell (HTC was 0.14 units). Weather conditions in August had a large amount of precipitation, $73.0 \mathrm{~mm}$, and high air temperatures ( $\mathrm{HTC}=1.21$ units).

\section{Results and discussion}

\section{Agrophysical indicators of soil fertility}

Chernozem soils have biological, agrophysical and agrochemical properties favourable for plants. Currently, many researchers point to the degradation of soil fertility.

This is due to intensive soil cultivation, violation of the regime of organic matter, insufficient application of mineral fertilizers, erosion processes, etc. [10].

No-till technology solves a number of indicated problems, however, it also has drawbacks [11-13]. It is believed that the cultivation of crops without tillage (Notill technology) leads to the problem of exposure of the running gear to the soil on harvesting machines and equipment destroying its structure and re-compaction.

One of the important indicators of the agrophysical properties of the soil is its density, which determines the water-air and biological properties, as well as the water permeability of the soil, water-holding ability, root distribution and the creation of favourable conditions for growing cultivated plants and yield.

In studies conducted on the southern chernozem of the Stavropol Territory, the cultivation of agricultural crops without tillage for 8 years led to a significant ( 3 times) decrease in the dust fraction and an increase in the water resistance of soil aggregates by $10.5-24.6 \%$ compared to traditional technology with tillage [14].

Our studies showed that as a result of autumn dump tillage, in a soil layer of $0-10 \mathrm{~cm}$ before sowing spring wheat, its density was $1.02 \mathrm{~g} / \mathrm{cm}^{3}$, whereas in the case without tillage it was $1.08 \mathrm{~g} / \mathrm{cm}^{3}$. In a soil layer of $10-20$ $\mathrm{cm}$ we observed a more substantial increase in soil density, from 1.08 to $1.20 \mathrm{~g} / \mathrm{cm}^{3}$. In the soil layer of 20 $30 \mathrm{~cm}$, there were no significant differences in density (Table 1).

The technology of cultivating spring wheat without tillage led to an increase in penetration resistance, especially in the soil layer of $20-30 \mathrm{~cm}$, but the indications did not go beyond the optimal values for plants.

The analysis of other indicators of soil water properties before sowing and before harvesting shows that traditional tillage (ploughing) is inferior to the option with direct sowing technology. Before sowing, we established that the reserves of productive water of 0$30 \mathrm{~cm}$ layer were $35.3 \mathrm{~mm}$ with traditional technology, and $40.2 \mathrm{~mm}$ with the No-till system. By harvest, the available moisture reserves decreased to $18.6 \mathrm{~mm}$ with ploughing, and up to $21.2 \mathrm{~mm}$ in direct sowing (Fig. 1).

\section{Dynamics of nitrogen content in the soil}

The content and availability of nitrogen in the soil are one of the most important indicators for creating a highquality crop. Our studies showed that the nitrogen content in the soil before sowing spring wheat was different and depends on technology. According to traditional soil cultivation in the spring, the soil contained $10 \mathrm{mg} / \mathrm{kg}$ of nitrate soil and $5.6 \mathrm{mg} / \mathrm{kg}$ of ammonia nitrogen soil. In direct sowing, the proportion of nitrate nitrogen decreased by 2 times, to $5.2 \mathrm{mg} / \mathrm{kg}$ of, but there was an increase in the concentration of ammonium nitrogen to $7.4 \mathrm{mg} / \mathrm{kg}$ of soil (Table 2).

The traditional technology of tillage with autumn ploughing contributed to an increase in the process of soil nitrification and increased in the content of nitrate nitrogen. The increase in the concentration of nitrate nitrogen because of ploughing indicates insufficient supply of carbon microorganisms with carbon compounds [15].

Before harvesting spring wheat, we did not reveal significant differences in the content of ammonium and nitrate nitrogen in the soil.

\section{Crop weediness}

Protecting plants from weediness is an important prerequisite for effective agricultural technologies. Many researchers point to an increase in weediness of crops when replacing ploughing with nonmoldboard cultivation, minimal and No-till technology [16-18]. However, modern agricultural technologies make it possible to control the weediness of crops through effective methods even without tillage [19].

Our studies showed a change in the quantitative and species composition of the weed component of cenosis in crops during the transition to direct sowing technology. In spring wheat sowing during traditional tillage, we found 6 species of weed plants, while using direct sowing technology we found 3 species.

No-till technology is distinguished by the creation of a mulching layer due to plant residues of previous crops, 
which reduces moisture loss and the germination of weed seeds.

However, it requires developing additional measures to protect crops from perennial weeds. During our research, we found only perennial weeds Convolvulus arvensis, Cirsium arvense and Euphorbia virgata in spring wheat crop. We did not notice any significant differences in the number of weeds: there were 16.5 $\mathrm{pcs} / \mathrm{m}^{2}$ with traditional tillage and $14.6 \mathrm{pcs} / \mathrm{m}^{2}$ using Notill technology, only the species composition was different (Table 3).

\section{Yield and quality of spring wheat}

Crop yield is an integral indicator of the efficiency of cultivation technologies. Analysis of the crop structure showed that direct sowing increased the number of grains in an ear and the weight of grain from 1 ear compared to traditional technology, which ensured a yield increase of $0.05 \mathrm{t} / \mathrm{ha}$. Also, when cultivating spring wheat using the No-till technology, there was an increase in gluten by $1.4 \%$ and protein by $0.6 \%$ (absolute values), in comparison with the technology involving ploughing (Table 4).

Table 1. Dynamics of soil density depending on the technology of cultivation of spring wheat.

\begin{tabular}{|c|c|c|c|c|}
\hline \multirow[t]{2}{*}{ Indicators } & \multirow{2}{*}{$\begin{array}{l}\text { Soil layer, } \\
\mathrm{cm}\end{array}$} & \multicolumn{2}{|c|}{ Technology options } & \multirow[t]{2}{*}{$\mathrm{LSD}_{05}$} \\
\hline & & Traditional & No tillage & \\
\hline \multicolumn{5}{|c|}{ Before sowing } \\
\hline \multirow{4}{*}{ Soil density, $\mathrm{g} / \mathrm{cm}^{3}$} & $0-10$ & 1.02 & 1.08 & 0.05 \\
\hline & $10-20$ & 1.08 & 1.19 & 0.07 \\
\hline & $20-30$ & 1.13 & 1.17 & 0.05 \\
\hline & 0-30 & 1.08 & 1.15 & 0.06 \\
\hline \multirow{4}{*}{ Soil moisture, $\%$} & $0-10$ & 21.3 & 22.2 & 1.2 \\
\hline & $10-20$ & 21.1 & 19.3 & 1.9 \\
\hline & $20-30$ & 21.1 & 19.7 & 2.0 \\
\hline & $\mathbf{0 - 3 0}$ & 21.2 & 20.4 & 1.9 \\
\hline \multirow{4}{*}{ Penetration resistance, $\mathrm{MPa}$} & $0-10$ & $7,8 / 0,76$ & $8,7 / 0,85$ & 2.1 \\
\hline & $10-20$ & $10,5 / 1,03$ & $16,4 / 1,61$ & 2.7 \\
\hline & $20-30$ & $12,0 / 1,18$ & $15,3 / 1,50$ & 2.9 \\
\hline & 0-30 & 10.1 & 13.4 & 2.4 \\
\hline \multicolumn{5}{|c|}{ Before harvesting } \\
\hline \multirow{4}{*}{ Soil density, $\mathrm{g} / \mathrm{cm}^{3}$} & $0-10$ & 1.11 & 1.12 & 0.05 \\
\hline & $10-20$ & 1.10 & 1.15 & 0.08 \\
\hline & $20-30$ & 1.13 & 1.18 & 0.03 \\
\hline & 0-30 & 1.11 & 1.15 & 0.06 \\
\hline \multirow{4}{*}{ Soil moisture, $\%$} & $0-10$ & 23.8 & 23.6 & 2.1 \\
\hline & $10-20$ & 23.3 & 22.5 & 3.4 \\
\hline & $20-30$ & 22.0 & 17.1 & 3.2 \\
\hline & 0-30 & 23.0 & 21.1 & 2.5 \\
\hline \multirow{4}{*}{ Penetration resistance, $\mathrm{MPa}$} & $0-10$ & 0.75 & 0.80 & 0.13 \\
\hline & $10-20$ & 0.86 & 1.04 & 0.23 \\
\hline & $20-30$ & 1.05 & 2.00 & 0.41 \\
\hline & $0-30$ & 0.89 & 1.28 & 0.4 \\
\hline
\end{tabular}

Table 2. Dynamics of the nitrogen content in the soil with various technologies for the cultivation of spring wheat

\begin{tabular}{|c|c|c|c|}
\hline \multirow[t]{2}{*}{ No. } & \multirow[t]{2}{*}{ Indicators } & \multicolumn{2}{|c|}{ Technology options } \\
\hline & & Traditional & No tillage \\
\hline \multicolumn{4}{|c|}{ Before sowing } \\
\hline 1 & Exchange ammonium nitrogen, $\mathrm{mg} / \mathrm{kg}$ & 5.6 & 7.4 \\
\hline \multirow[t]{2}{*}{2} & Nitrate nitrogen, $\mathrm{mg} / \mathrm{kg}$ & 10.0 & 5.2 \\
\hline & $\mathrm{LSD}_{05}$ & 3.6 & 1.8 \\
\hline \multicolumn{4}{|c|}{ Before harvesting } \\
\hline 3 & Exchange ammonium nitrogen, $\mathrm{mg} / \mathrm{kg}$ & 5.4 & 5.6 \\
\hline \multirow[t]{2}{*}{4} & Nitrate nitrogen, $\mathrm{mg} / \mathrm{kg}$ & 7.0 & 3.6 \\
\hline & $\mathrm{LSD}_{05}$ & $\mathrm{Ff} \leq \mathrm{Ft}$ & $\mathrm{Ff} \leq \mathrm{Ft}$ \\
\hline
\end{tabular}


Table 3. Quantitative and species composition of the weed component of agrophytocenoses with spring wheat using various technologies

\begin{tabular}{|c|c|c|c|c|}
\hline No. & Technology & Weed species & $\begin{array}{c}\text { Number of } \\
\text { weeds, pcs } / \mathrm{m}^{2}\end{array}$ & $\begin{array}{c}\text { Total weeds, } \\
\text { pcs } / \mathbf{m}^{2 *}\end{array}$ \\
\hline \multirow[t]{6}{*}{1} & \multirow[t]{6}{*}{ Traditional } & Chenopodium album & 1.3 & \multirow[t]{6}{*}{$16,5 / 10,3$} \\
\hline & & Descurainia sophia & 4.0 & \\
\hline & & Echinochloa crus-galli & 0.6 & \\
\hline & & Elytrigia repens & 0.3 & \\
\hline & & Convolvulus arvensis & 7.3 & \\
\hline & & Euphorbia virgata & 3.0 & \\
\hline \multirow[t]{3}{*}{2} & \multirow[t]{3}{*}{ No tillage } & Convolvulus arvensis & 13.3 & \multirow[t]{3}{*}{$14,6 / 14,6$} \\
\hline & & Cirsium arvense & 1.0 & \\
\hline & & Euphorbia virgata & 0.3 & \\
\hline
\end{tabular}

* - number above the line indicates the total weeds, number below the line includes perennial weeds

Table 4. Yield and grain quality of spring wheat

\begin{tabular}{|c|l|c|c|c|}
\hline No. & \multicolumn{1}{|c|}{ Indicators } & Traditional & No tillage & LSD $_{05}$ \\
\hline 1 & Grain size, $g / 1$ & 738 & 738 & 14 \\
\hline 2 & Falling number & 180 & 108 & - \\
\hline 3 & Moisture, $\%$ & 12.4 & 13.6 & - \\
\hline 4 & Mass fraction of gluten, $\%$ & 13.6 & 15.0 & 1.3 \\
\hline 5 & Mass fraction of protein, $\%$ & 11.0 & 11.6 & 0.9 \\
\hline 6 & Productivity, $t /$ ha & 1.65 & 1.70 & 0.17 \\
\hline
\end{tabular}

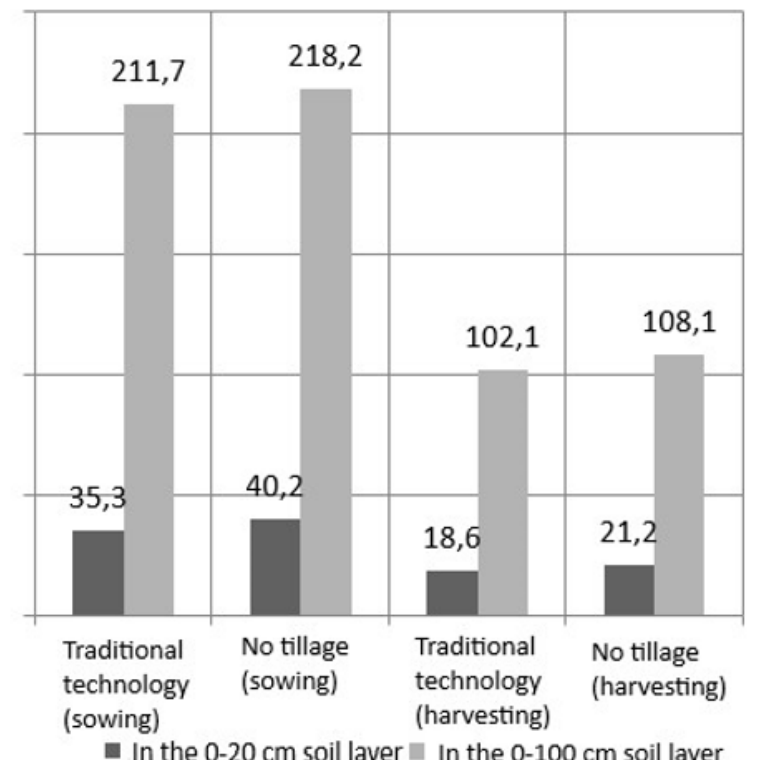

Fig. 1. Productive moisture content in soil depending on cultivation technologies, $\mathrm{mm}$

\section{Conclusion}

Preliminary results allow us to note that in the conditions of our region, No-till technology does not lead to a deterioration in the agrophysical and agrochemical properties of typical chernozem, the number of weed plants has not changed much compared to traditional technology. In terms of productive moisture reserves, both in arable $0-30 \mathrm{~cm}$ and meter soil layers, direct sowing technology exceeded the traditional technology and resulted in the higher yield with the best quality indicators.
Studies conducted in various soil and climatic conditions show that the direct sowing system helps to reduce the intensity or eliminate the manifestation of erosion processes, significantly reduce the loss of soil organic matter, reduce soil contamination, increase yield and product quality [20-22]. These directions are relevant for the conditions of the forest-steppe zone of the Volga region, which makes it necessary to continue research to assess the effectiveness of this technology.

This work has been implemented under the support of grant MD-2909.2019.11.

\section{References}

1. C.R. Ferreira, C. dos Reis; N. da Silva, E. Carvalho, M.G. Pereira et al., Dynamics of soil aggregation and organic carbon fractions over 23 years of no-till management, Soil \& Tillage Research, 198 (2020)

2. V.K. Dridiger, R.S. Stukalov, R.G. Gadzhiumarov, Influence of plant residues on moisture accumulation and the population of earthworms during cultivation of field crops using No-till technology, in: New methods and results of landscape studies in Europe, Central Asia and Siberia: monograph in 5 volumes, Volume IV: Optimization of agricultural landscapes, pp. 134139 (All-Russian Research Institute of Agricultural Chemistry, Moscow, 2018)

3. A. Toigildin, V. Morozov, M. Podsevalov, D. Ayupov et al., Factors of biologization of farming in the forest-steppe zone of Volga region, $\mathrm{BIO} \mathrm{Web}$ of Conferences, 00173 (2020)

4. G.V. Mokrikov, K.Sh. Kazeev, Yu.V. Akimenko et al., Influence of no-till technology on the ecological 
and biological state of soils (Rostov-on-Don, 2017) $140 \mathrm{p}$.

5. L-J.T. Hess, E-L.S. Hinckley, G.P. Robertson, S. Hamilton, P.A. Matson, Rainfall Intensification Enhances Deep Percolation and Soil Water Content in Tilled and No-Till Cropping Systems of the US Midwest, Vadose zone journal, 17, 1 (2018)

6. V.K. Dridiger, V.V. Belobrov, R.S. Stukalov, Results of research on direct sowing technology in the zone of unstable moisture in the Stavropol Territory, Agricultural Journal, S5(12), 51-59 (2019)

7. H. Blanco-Canqui, C.S. Wortmann, Does occasional tillage undo the ecosystem services gained with notill? A review, Soil \& Tillage Research, 198, 104534 (2020)

8. B.A. Dospekhov, Field Experience Methodology, (Kolos, Moscow, 1985), (Agropromizdat, Moscow, 1985)

9. B.D. Kiryushin, R.R. Usmanov, I.P. Vasiliev, Fundamentals of scientific research in agronomy (KolosS, Moscow, 2009)

10. He Huang, Chaolan Zhang, Qun Rong, Effect of two organic amendments on atrazine degradation and microorganisms in soil, Applied Soil Ecology, 152, 103564 (2020)

11. J.M. Jemison, S. Welcomer, R. Kersbergen, C. Majewski, Word cloud analysis of early adopter notill farmer interviews, Journal of Extension, 56(3), \#3RIB3 (2018)

12. İ. Çelik, H. Günal, M. Acar et al., Strategic tillage may sustain the benefits of long-term no-till in a Vertisol under Mediterranean climate, Soil and Tillage Research, 185, 17-28 (2019)

13. A.A. Zavalin, V.P. Belobrov, S.A. Yudin, V.K. Dridiger, Nitrogen in chernozems under traditional and direct seeding cropping systems: A review, Eurasian Soil Science, 51(12), 1497-1506 (2018)

14. G.R. Dorozhko, O.I. Vlasova, O.G. Shabaldas, T.G. Zelenskaya, Effect of prolonged use of direct sowing on the main agrophysical factors of soil fertility and winter wheat productivity in the arid zone, Agriculture, 7, 7-10 (2017)

15. S.S. AL-Ismaily, J.L. Walworth, Effects or osmotic and matric potentials on nitrogen mineralization in unamended and manure-amended soils, Soil Science, 173(3), 203-213 (2008)

16. D.V. Dubovik, V.I. Lazarev, A. Ya. Aidiev et al., Efficiency of Various Methods of Primary Tillage and Direct Sowing During the Cultivation of Winter Wheat on Chernozem Soils, Advances in science and technology of AIC, 33(1), 26-29 (2019)

17. E. Lehoczky, A. Kismanyoky, T. Nemeth, Effects of Nutrient Supply and Soil Tillage on the Weeds in Maize, Communications in Soil Science and Plant Analysis, 44(1-4), 546-550 (2013)

18. V.G. Vasin, A.V. Vasin, A.N. Burunov et al., Influence of soil tillage, fertilizers and biostimulants on the yield of spring wheat in the forest-steppe of the Middle Volga, IOP Conference Series: Earth and Environmental Science, 422(1), 012017 (2019)

19. N. Nikolic, A. Squartini, G. Concheri et al., Weed seed decay in no-till field and planted riparian buffer zone, Plants-Basel, 9(3), 293 (2020)

20. S.M. Ogle, C. Alsaker, J. Baldock et al., Climate and Soil Characteristics Determine Where No-Till Management Can Store Carbon in Soils and Mitigate Greenhouse Gas Emissions, Scientific Reports, 9(1), 11665 (2019)

21. J. S. Cavalcante, N. Favaretto, J. Dieckow et al., Long-term surface application of dairy liquid manure to the soil under no-till improves carbon and nitrogen stocks, European Journal of Soil Science (2019)

22. V.A. Milyutkin, V.E. Buksman, M.A. Kanaev, Highperformance equipment for energy-, moisture-, resource-saving world technologies mini-till, no-till in the system of precision farming in Russia (Kinel, 2018) 